\title{
Comparative Infiltration Rates and Sediment Production on Fertilized and Grazed Blue Grama Rangeland
}

\author{
M. KARL WOOD, GARY B. DONART, AND MARK WELTZ
}

\begin{abstract}
This study determined the impacts of fertilization and livestock grazing on infiltration rates and sediment production. Infiltration rates and sediment production varied across years, depending on precipitation conditions, but were not different between fertilized and unfertilized rangeland within a year. Livestock production and stocking rates were 2 times greater on fertilized than on nonfertilized rangeland.

Soil bulk density was only greater on the fertilized areas than the control at the end of the grazing period in 1982. Microtopography or roughness was not different between treatments. Increases in plant production mitigated any impacts from increased livestock numbers in fertilized areas.
\end{abstract}

Increased rangeland forage production is necessary to meet long-term demands for red meat production. Most rangelands are being grazed to near capacity, but far below their potential. The level of forage production can be no greater than that allowed by the most limiting of the essential plant growth factors. These factors include light, mechanical support, heat, air, water, and nutrients. Humphrey (1962) noted that range forage production is limited more by nitrogen deficiency than any other element.

Improving range condition has increased infiltration rates and decreased sediment yields on many sites across the United States (Dee et al. 1966, Rauzi and Zingg 1956, Blackburn and Skau 1974, Wood and Blackburn 1981). Only scant information exists linking improved range conditions to fertilization and grazing. In a related study, Rauzi and Smika (1963) applied $90 \mathrm{~kg} / \mathrm{ha}$ of nitrogen to blue grama (Bouteloua gracilis)/western wheatgrass (Agropyron smithii)/needleandthread (Stipa comata)/green needlegrass (Stipa viridula)/threadleaf sedge (Carex filifolia) dominated rangeland on a silt loam soil site in North Dakota. Frequently clipped fertilized plots had water intake rates statistically similar $(P<0.05)$ to similar clipped unfertilized plots. Water intake rates for frequently clipped fertilized plots were significantly lower than for fertilized plots that were clipped once in the fall with none of the herbage returned. They were also lower than on fertilized and unfertilized plots that had half the herbage returned.

The impacts on infiltration rates and sediment production from fertilizing rangeland and doubling the stocking rate compared to unfertilized rangeland with conventional stocking are not known. The objectives of this study were to determine the impacts of fertilization and subsequent grazing on infiltration rates and sediment production.

\section{Description of Study Areas}

An area in good range condition on the Ft. Stanton Experimental Ranch in Lincoln County, New Mexico, was chosen for study and was partitioned into 55- and 63-ha treatment areas in 1968. The areas were fertilized with $45 \mathrm{~kg} /$ ha of actual nitrogen, in the form of urea, in mid-June each year through 1976. After 1976, fertilizer was applied only in even-numbered years. Each area contained similar amounts of blue grama (Bouteloua gracilis H.B.K. (Griffiths)), the dominant species (Donart et al. 1978). Other species of importance were hairy grama (B. hirsuta Lag.),

Authors are associate professor, professor, and former graduate student, Department of Animal and Range Sciences, New Mexico State University, Las Cruces, 88003. This article is published as Journal Article 1167, Agricultural Experiment Station, New Mexico State University, Las Cruces 88003-0009.

Manuscript accepted 21 October 1985. sideoats grama (B. curtipendula (Michx.) Torr.), ring muhly (Muhlenbergia torreyi (Kunth) Hitchc. \& Chase), mat muhly ( $M$. richardsonis (Trin.) Rydb.), slimstem muhly (M. filiculmis Vasey), vine mesquite (Panicum obtusum H.B.K.), and galleta (Hilaria jamesii (Torr.) Benth). Soils were fine-loamy, mixed, mesic, Cumulic Haplustolls (Bailey et al. 1982). Slopes were uniform and $2-3 \%$.

Average annual precipitation over the past 79 years was $348 \mathrm{~mm}$. Growing season precipitation, June through September, averaged $244 \mathrm{~mm}$. Monthly precipitation values for the years in which this study was conducted are given in Figure 1. Since 1978, 3 unfertilized (control) areas have been moderately stocked with an average

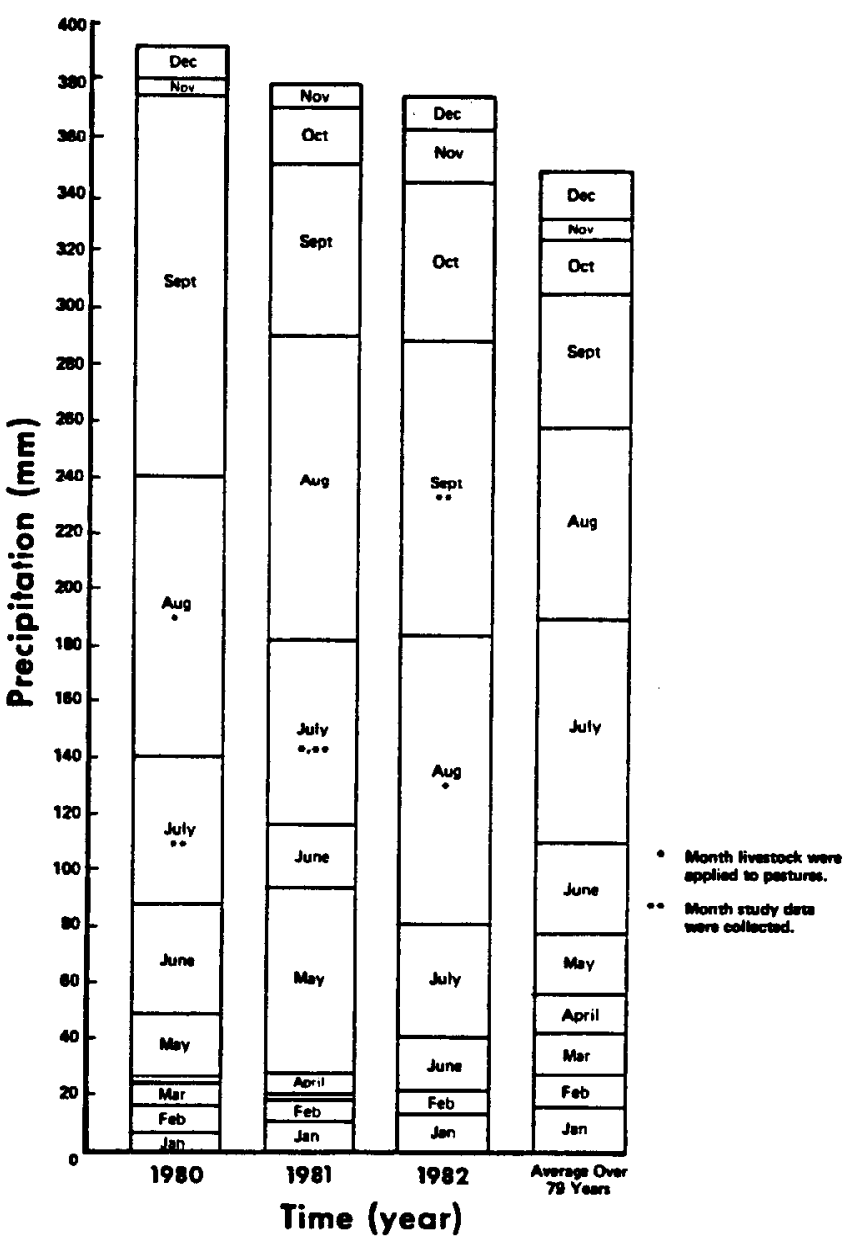

Fig. 1. Precipitation for each month within the study and averaged over 79 years.

of about 2.5 ha/AU (animal unit). Three fertilized areas were stocked at least twice as heavy for an average of about $1.2 \mathrm{ha} / \mathrm{AU}$. Areas were stocked with yearling heifers about 1 week after initiation of summer growth and were grazed until late September or October. Length of grazing periods varied according to starting time and amount of growth. Livestock were turned in on 14 August 
and out on 20 October 1984; turned in on 8 July and out on 30 September 1981 ; and turned in on 10 August and out on 3 October 1982.

\section{Methods}

Six study sites were selected. Three areas represented the fertilized treatment and 3 areas represented the control of unfertilized treatment. Four square plots $\left(1 \mathrm{~m}^{2}\right)$ were randomly located within each area for a total of 12 plots per treatment. Plot borders consisted of $10-\mathrm{cm}$ high metal frames. The inference technique described by Tueller and Blackburn (1974) was used to select study areas. This approach assumes it is possible to select sites with similar soils, elevations, slopes, and aspects so the potential of all sites to produce a certain kind and amount of vegetation is similar. If the vegetation is found in different ecological range conditions, then major variations in the vegetation community and associated soil surface morphology should be attributable to prior management effects such as grazing or fertilization. In 1980 and 1981 , hydrologic and vegetal data were collected before summer growth began and before introduction of livestock. In 1982, data were collected in mid-September, which represented the time period when summer growth is nearing completion and the grazing period was about half completed.

On each plot, a mobile drip type infiltrometer (Blackburn et al. 1974) was used to simulate rainfall at a rate of $7.5 \mathrm{~cm} / \mathrm{hr}$ for 45 minutes. This storm intensity with a duration of 1 hour occurs only once every 100 years (Hershfield 1961). Storms of this intensity but with shorter time periods will occur nearly every year. Preliminary tests showed $\mathbf{4 5}$ minutes were required for the soil moisture deficit to be filled and a constant infiltration rate be obtained. Simulated rainfall was applied to the plots until runoff occurred. Plots were then covered with a clear polyethylene plastic to prevent evaporation. This ensured fairly uniform soil moisture conditions for a second simulated rainfall application 24 hours later. Data collected from the first simulated rainfall application were highly variable but showed similar trends to the second data set collected when the soil was at field capacity. Therefore, only the results of the second readings are reported here.

All runoff was collected from the bottom of each plot at 5-minute intervals and weighed on-site and converted to a depth $(\mathrm{cm})$ of runoff. The infiltration rate was determined by subtracting measured runoff rate from rainfall rate. Under these conditions, the infiltration rate is the infiltration capacity.

Total runoff collected from each plot was thoroughly agitated and a 1-liter subsample removed. Sediment was filtered off the subsample, dried at $100^{\circ} \mathrm{C}$ for 24 hours, weighed, and converted to sediment yield in kilograms per hectare.

Foliar crown cover estimates of grasses and forbs, and cover estimates of rock, litter, and bare ground were made at 6 transect lines evenly spaced across each plot using the line intercept method. Readings were taken on all plots after the second simulated rainfall. Foliar cover included all plant parts that would intercept a raindrop. Rock was pebble size particles $(>2 \mathrm{~mm})$ or larger. Grasses and forbs, both standing live and dead, were clipped at $1.5-\mathrm{cm}$ stubble height, and litter was collected from each $1 \mathrm{~m}^{2}$ plot. Biomass material was dried at $60^{\circ} \mathrm{C}$ for 1 week and weighed.

A micro-relief meter was used to determine surface roughness in each plot (Kincaid and Williams 1966). The variation was obtained by averaging differences for 3 transects with 20 points per transect, per plot. Uniformity of soil moisture between plots after the initial wetting was verified by using a gravimetric technique (Black 1965) from 0-5 and 5-10 cm depth. Bulk density was determined by the core method (Black 1965). Uniformity of soil texture was verified by the hydrometer method (Bouyoucos 1962).

Data normality was determined by tests for skewness and kurtosis. Student's $t$-test, based on a randomized design, was used to determine if any significant differences existed between means for both the dependent and independent variables $(P<10)$ within each year. Simple linear regression and step-wise multiple regression analysis was used to select the highest correlated soil and vegetation variables influencing infiltration rates and sediment production.

\section{Results and Discussion}

Infiltration rates are shown for each treatment within each year in Figure 2 and Table 1. Mean soil moisture content was $21.8 \%$. Time to ponding occurred within the first 5 minutes for every treatment. Infiltration rates declined with time but approached a

Table 1. Dependent and independent variable means for fertilized and control treatments in 1980, 1981 , and 1982.

\begin{tabular}{|c|c|c|c|c|c|c|c|c|}
\hline \multirow[b]{2}{*}{ Variable } & \multicolumn{2}{|c|}{1980} & \multicolumn{2}{|c|}{1981} & \multicolumn{2}{|c|}{1982} & \multicolumn{2}{|c|}{ Overall } \\
\hline & Control & Fert. & Control & Fert. & Control & Fert. & Control & Fert. \\
\hline $\begin{array}{l}\text { Terminal } \\
\text { Infiltration Rate } \\
(\mathrm{cm} / \mathrm{hr})\end{array}$ & & & & & & & & \\
\hline $\begin{array}{l}\text { Sediment Production } \\
(\mathrm{kg} / \mathrm{ha})\end{array}$ & $4.3 \mathrm{~d}$ & $4.4 \mathrm{a}$ & $3.9 \mathrm{a}$ & 5.00 & $4.0 \mathrm{a}$ & $1041 \mathrm{~b}$ & 4.0 & 4.6 \\
\hline Biomass (kg/ha) & & & & & & & & (50) \\
\hline $\begin{array}{l}\text { grass } \\
\text { forb } \\
\text { litter } \\
\text { Total }\end{array}$ & $\begin{array}{l}46 a \\
11 a \\
19 a \\
76 a\end{array}$ & $\begin{array}{l}25 b \\
21 b \\
15 a \\
61 a\end{array}$ & $\begin{array}{r}117 \mathbf{a} \\
55 a \\
26 a \\
197 a\end{array}$ & $\begin{array}{r}120 \mathrm{a} \\
20 \mathrm{~b} \\
126 \mathrm{~b} \\
266 \mathrm{~b}\end{array}$ & $\begin{array}{l}45 \mathbf{a} \\
33 \mathbf{a} \\
* \\
*\end{array}$ & $\begin{array}{l}90 b \\
35 a \\
* \\
*\end{array}$ & $\begin{array}{r}72 \\
33 \\
22 \\
136\end{array}$ & $\begin{array}{r}78 \\
25 \\
70 \\
164\end{array}$ \\
\hline Cover $(\%)$ & & & & & & & & \\
\hline $\begin{array}{l}\text { grass } \\
\text { forb } \\
\text { rock } \\
\text { litter } \\
\text { Total }\end{array}$ & $\begin{array}{r}17 a \\
<1 a \\
<1 a \\
1 a \\
20 a\end{array}$ & $\begin{array}{r}13 b \\
2 a \\
<1 a \\
<1 a \\
16 a\end{array}$ & $\begin{array}{r}46 \mathrm{a} \\
17 \mathrm{a} \\
0 \mathrm{a} \\
3 \mathrm{a} \\
66 \mathrm{a}\end{array}$ & $\begin{array}{l}58 b \\
11 a \\
<1 a \\
14 b \\
84 b\end{array}$ & $\begin{array}{r}13 a \\
2 a \\
1 a \\
<1 a \\
16 a\end{array}$ & $\begin{array}{r}27 \mathrm{~b} \\
2 \mathrm{a} \\
<1 \mathrm{a} \\
1 \mathrm{a} \\
31 \mathrm{~b}\end{array}$ & $\begin{array}{r}25 \\
7 \\
1 \\
2 \\
35\end{array}$ & $\begin{array}{r}33 \\
5 \\
1 \\
5 \\
44\end{array}$ \\
\hline $\begin{array}{l}\text { Microtopography } \\
\text { or Roughness (cm) }\end{array}$ & $0.65 a$ & $0.68 \mathrm{a}$ & $1.41 \mathrm{a}$ & $1.39 \mathrm{a}$ & $0.90 \mathrm{a}$ & $1.14 \mathrm{a}$ & 0.99 & 1.07 \\
\hline $\begin{array}{l}\text { Bulk Density } \\
\left(\mathrm{g} / \mathrm{cm}^{3}\right)\end{array}$ & $1.04 \mathrm{a}$ & $1.15 \mathrm{a}$ & $1.36 \mathrm{a}$ & $1.36 \mathrm{a}$ & $1.26 \mathrm{a}$ & $1.37 \mathrm{~b}$ & 1.22 & 1.29 \\
\hline
\end{tabular}

* Missing data.

* Means followed by the same letter within a variable and year are not significantly different $(P<0.10)$. 


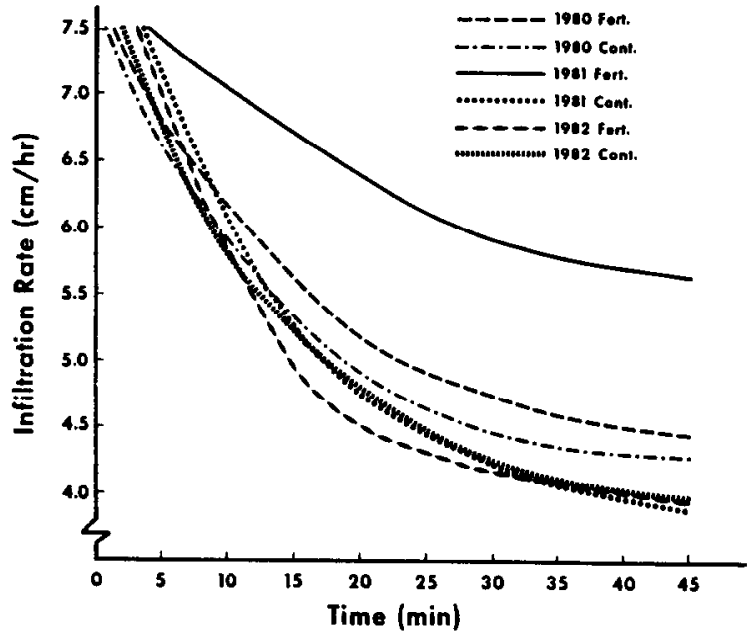

Fig. 2. Mean infiltration rates for fertilized and control treatments for each year.

constant rate by $\mathbf{4 5}$ minutes for all treatments. These curves suggest runoff started soon after rainfall began. The $45 \mathrm{~min}$ (terminal) infiltration rates did not differ in the unfertilized or control plots from one year to another (Table $1, P \leq 0.10$ ). Terminal infiltration rates were similar between fertilized and control treatments in 1980 and 1982. In 1981 the fertilized treatment plots were $44 \%$ higher than the control. Over all years, infiltration rates were greater in the fertilized treatment.

Regression analysis on data for each treatment within each year indicated the primary factors positively affecting infiltration rates were plant cover, litter cover, live and dead plant biomass, and micro-relief. Bulk density from 0 to $5 \mathrm{~cm}$ depth and rock cover had a negative influence. Fifty-eight percent of the variability in infiltration was accounted for in the control plots among years while only $39 \%$ was accounted for in the fertilized treatment. Apparently the control areas produced less vegetation with less variability than the fertilized areas. Bulk density was important in the control every year, but was never important in the fertilized treatment, and this treatment had twice as many livestock as the control which would lead to twice as much trampling. There were no differences in bulk density for the 2 treatments in 1980 and 1981 because of frost heaving in the spring, but a significant difference was found in 1982 (Table 1), possibly because the sampling was conducted a month after livestock were applied in this final year. Grass cover was useful in predicting infiltration rates every year for both treatments, as was biomass. Cover and total biomass were greater in the fertilized treatment than the control in 1981, which corresponds to the increased infiltration rate. Significant amounts $(118 \mathrm{~mm})$ of rainfall occurred in 1981 before sampling and before grazing which gave the high total biomass and cover values for that year.

\section{Sediment Production}

Sediment production was quite variable between years (Table 1). Three to 10 times more sediment was measured in 1982 than in 1980 and 1981 . In 1982, treatments were evaluated after a significant period of grazing when biomass and foliar cover was quite low. Even though fertilization produced twice as much biomass and cover as the control and this treatment was applied in conjunction with a doubled livestock stocking rate. With twice as many livestock, the sediment production from the fertilized treatment was still significantly less than the control. Also, less sediment was measured in the fertilized treatment in 1981 than for the control. Sediment production was similar between treatments when all years were combined.

Values for $\boldsymbol{R}^{2}$ for sediment production averaged 0.72 for the control and 0.71 for the fertilized teatment across all years, with all independent variables included in the regression model. This compares to only $58 \%$ and $39 \%$ for terminal infiltration rate variables from the same respective treatments. Microtopography was selected for the regression equation for the fertilized treatment all 3 years and for the control in 1981. This was attributed to increased hoof action in the fertilized areas. Plant cover and biomass were the dominant variables and rock cover was positively correlated with sediment production. The sediment production represents interrill or sheet erosion, which probably is the majority of erosion taking place on this physiographic feature. Rill and gully erosion were not observed with a microrelief meter and probably are not present on this site because of foliar cover and dispersion, and microtopography or roughness of the soil surface. Approximately $14 \%$ of the total precipitation occurred at the simulated intensity. Only a fraction of the total precipitation each year was received at the intensity of the simulated storm in this study. The rest is received as snow, or at lower intensities which have lower erosive energies. If all the precipitation were received at this intensity, it is estimated that annual sediment production could be as high as 10 tons per hectare based on levels from the control in 1982.

\section{Biomass}

Plant biomass varied because of the amount of precipitation, fertility levels, grazing pressure, and time of sampling. At the time of sampling in 1980, the treated area had not been grazed. Little growth had resulted from fertilization because of a low amount of precipitation between fertilizing and sampling. The fertilizer was applied as a pellet and needed rainfall to dissolve and transport it to plant roots. Although biomass totals for 1980 are similar, significantly more grass was found in the control and more forbs in the fertilized areas. These differences may represent residue from grazing in 1979.

At the time of sampling in 1981, grass biomass was similar between treatments while more forbs were found in the control, the reverse of the previous year, and more litter was found in the fertilized areas. Litter or dead plant materials fall to the soil surface, are trampled or washed into the soil, oxidize, blow away, or are eaten. Litter apparently was being produced faster than it was changing form. This may be attributed to unusually high levels of precipitation in May (65.8 mm vs. 23.6 normally), which produced plant growth in May with curing during June before sampling in July.

Sampling in 1982 was conducted after the areas received large amounts of precipitation during July, August, and early September. Grass biomass in the fertilized areas was double that in the control areas, indicating production increases greater than the stocking rate increase. Forb biomass seemed to respond to precipitation in May and June, as in 1980 and 1981, and was not attributed to fertilization. Only litter biomass was significantly different between treatments when all years were combined.

\section{Cover}

Most plant cover was associated with grass vegetation and fluctuated similarly to biomass. Foliar cover is more sensitive to environmental changes than basal cover and correlates better with the hydrologic variables, runoff, infiltration rate, and sediment production (Wood 1984). In this soil, rock cover was low (mean of $1 \%$ or less) but was identified as an important variable by regression techniques. Rock cover values range from 0 to $5 \%$. Forb and litter cover corresponded to biomass levels. Year-to-year fluctuations were as great as $68 \%$, from $16 \%$ in 1980 to $84 \%$ in 1981 . This shows the tremendous variability that can result from different combinations of precipitation, fertilization, and grazing. Grass and litter cover were significantly greater in the fertilized treatment than the control when all years were combined.

\section{Microtopography}

This variable did not change much across treatments within any 
year (Table 1). These data represent seasonal as well as yearly changes because data were collected after a dry spring (Fig. 1) and no livestock in 1980, a wet spring and no livestock in 1981, and a wet summer with livestock in 1982 . Microtopography or surface roughness may be influenced by shrinking and swelling of the soil from wetting and drying, and freezing and thawing. Hoof action from livestock may increase the roughness during wet periods and decrease it during dry periods. Energy from precipitation may also flatten the soil surface. When all years were combined, there was not a significant difference in treatments for microtopography.

\section{Bulk Density}

This variable was different between treatments only in 1982, and was attributed to summer precipitation and livestock hoof action. At this site, increases in bulk density are mitigated each year from shrinking and swelling, especially during winter and early spring. Bulk density across years was not significantly different between treatments.

\section{Conclusions}

Increasing the stocking rate to double the rate in the control did not adversely affect infiltration rates and sediment production if the plant response was great enough to provide adequate forage for livestock at stocking levels considered proper for maintaining range condition. Season-to-season and year-to-year differences in infiltration and sediment production can be tremendous, but were all considered to be within safe limits in this study.

\section{Literature Cited}

Bailey, O.F., L.A. Daugherty, and G.B. Donart. 1983. Soil survey of the Fort Stanton Experimental Ranch-Phase I. New Mexico State Univ. Agr. Exp. Sta. Special Report 43.

Black, C.A. 1965. Methods of Soil Analysis. Amer. Soc. Agron. Series No. 9. Madison, Wis.
Blackburn, W.H., and C.M. Skau. 1974. Infiltration rates and sediment production of selected plant communities in Nevada. J. Range Manage. 27:476-479.

Blackburn, W.H., R.O. Meeuwig, and C.M. Skau. 1974. A mobile infiltrometer for use on rangeland. J. Range Manage. 27:322-323.

Bouyoucos, G.J. 1962. Hydrometer method approved for making particle size analysis of soil. Agron. J. 54:464-465.

Dee, R.F., T.W. Box, and E. Robertson, Jr. 1966. Influence of grass vegetation on water intake of Pullman silty clay loam. J. Range Manage. 19:77-79.

Donart, G.B., E.E. Parker, R.D. Pieper, and J.D. Wallace. 1978. Nitrogen fertilization and livestock grazing on blue grama rangeland. Proceed. Int. Rangeland Congress. Soc. Range Manage. (Denver, Colo.)

Hershfield, D.M. 1961. Rainfall frequency atlas for the United States. U.S. Dep. Commerce Tech. Paper No. 40.

Humphrey, R.R. 1962. Range ecology. Ronald Press Co., New York, N.Y.

Kincaid, D.R., and G. Williams. 1966. Rainfall effects on soil surface characteristics following range improvement treatments. J. Range Manage. 19:346-351.

Rauxi, F., and D.E. Smika. 1963. Water intake on rangeland as affected by simulated grazing and fertilization. J. Range Manage. 16:125-128.

Raudi, F., and A.W. Zings. 1956. Rainmaker helps prove a theory. Soil Conserv. 21:228-229.

Tueller, P.T., and W.H. Blackburm. 1974. Condition and trend of the big sagebrush/needleandthread habitat type in Nevada. J. Range Manage. 27:36-40.

Wood, J.C. 1983. Best management practices for improving infiltration and runoff water quality on New Mexico rangeland. M.S. Thesis. New Mexico State Univ.

Wood, M.K. 1984. Describing and quantifying water resources with small plots on rangelands. Proceed. 2nd Int. Rangeland Congres. Soc. Range Manage. Adelaide, Australia. (In Press).

Wood, M.K., and W.H. Blackburn. 1981. Grazing systems: their influence on infiltration rates in the Rolling Plains of Texas. J. Range Manage. 34:331-335. 